\title{
Antibacterial and Anti-Inflammatory Potential of Polyherbal Formulation Used in Chronic Wound Healing
}

\author{
Ilona Mandrika $\mathbb{D}^{1,2}$ Somit Kumar, ${ }^{1,3}$ Baiba Zandersone, ${ }^{1}$ Sujith Subash Eranezhath, ${ }^{3}$ \\ Ramona Petrovska, ${ }^{2}$ Iveta Liduma, ${ }^{1}$ Arnolds Jezupovs, ${ }^{1}$ Valdis Pirags, ${ }^{1}$ \\ and Tatjana Tracevska ${ }^{1}$ \\ ${ }^{1}$ Faculty of Medicine, University of Latvia, Riga 1004, Latvia \\ ${ }^{2}$ Latvian Biomedical Research and Study Centre, Riga 1067, Latvia \\ ${ }^{3}$ AVP Research Foundation, Coimbatore 641045, India \\ Correspondence should be addressed to Ilona Mandrika; ilona@biomed.lu.lv
}

Received 4 April 2021; Revised 16 June 2021; Accepted 25 June 2021; Published 7 July 2021

Academic Editor: Youhua Xu

Copyright (c) 2021 Ilona Mandrika et al. This is an open access article distributed under the Creative Commons Attribution License, which permits unrestricted use, distribution, and reproduction in any medium, provided the original work is properly cited.

Objective. Polyherbal formulations Jathyadi Thailam and Jatyadi Ghritam (JT) are used in Indian traditional medicine for diabetic chronic wounds, fistula, fissure, eczema, and burn management. We aimed to investigate the antibacterial and anti-inflammatory properties of crude hexane and ethanol extracts of JT formulations. Methods. Antibacterial activity of JT extracts was tested to estimate minimum inhibitory concentrations (MICs) against nine reference bacterial strains, including one methicillin-resistant Staphylococcus aureus (MRSA) and multidrug-resistant (MDR) Pseudomonas aeruginosa, and clinical strains of methicillinsusceptible S.aureus (MSSA), all involved in diabetic foot infection. The anti-inflammatory activity of plant extracts was evaluated in LPS-treated macrophage cells by measuring the mRNA levels and secretion of inflammatory mediators. Results. The antibacterial activity of $J T$ extracts was higher against Gram (+) bacteria, with the MICs varying from 1.95 to $62.5 \mathrm{mg} / \mathrm{mL}$. Gram $(-)$ bacteria were only susceptible to ethanol extracts of JT. Plant extracts were found to be the most active against the reference and clinical strains of MSSA, MRSA, and biofilm-forming S. epidermidis. JT extracts efficiently inhibited in a dose-dependent manner the mRNA expression and protein secretion of proinflammatory cytokines IL- 6 and IL- $1 \beta$, and chemokines MCP- 1 and CXCL10 in LPS-challenged macrophages. Conclusion. In the present study, we have shown that extracts of JT formulations possess potent antibacterial and anti-inflammatory properties that could be involved in chronic wound healing activity and has the potential to be used as external add-on therapy in the management of multidrug-resistant bacterial infections at the wound.

\section{Introduction}

Diabetes is a chronic metabolic disease characterized by prolonged hyperglycemia, which can lead to eyes, kidneys, nerves, blood vessel damage, and nonhealing wounds $[1,2]$. The normal wound healing process involves overlapping phases of hemostasis, inflammation, proliferation, and remodelling and requires a coordinated interplay between macrophages, fibroblasts, keratinocytes, epithelial cells, and signalling molecules. Macrophages play a critical role in the inflammatory phase of wound repair by killing pathogens, clearing damaged tissues, and producing growth factors that induce angiogenesis, collagen deposition, and wound closure [3]. During impaired healing of wounds associated with diabetes, it exhibits prolonged accumulation of M1-polarized macrophages associated with elevated levels of proinflammatory cytokines and reduced levels of various growth factors. It has been demonstrated that IL- $1 \beta$, TNF- $\alpha$, IL- 6 , and MCP-1 levels are sustained at high levels in chronic wounds of diabetic mice and humans [4].

Further, the diabetic wound environment with the resident cells and their secreted signalling molecules could be significantly influenced by the bacterial colonisation in the wound. It has been shown that diabetic mouse wounds 
inoculated with Pseudomonas aeruginosa biofilm displayed higher levels of IL- $1 \beta$ and IL- 6 than control wounds even at 4 weeks postwounding [5]. Diabetic foot ulcer infections (DFI) are mostly polymicrobial, involving both aerobic and anaerobic bacteria that grow in synergy $[6,7]$. Recent studies have revealed that Gram (+) cocci, mostly Staphylococcus aureus, are the main microorganisms responsible for DFI in occidental countries, but in Asia and Africa, Gram (-) bacilli are predominant. Among the $S$. aureus pathogen, methicillin-resistant S. aureus (MRSA) was found in $11 \%$ of the DFI isolates [8]. Multidrug-resistant bacterial infections are growing worldwide as a serious problem and this urges the immediate need for the search for alternatives.

The use of medicinal plants and herbs with oils or clarified butter as oleaginous products is a common practice in Indian traditional medicine. These practices have got enshrined in the traditional books as medicated oil (Thailam) and medicated clarified butter or ghee (Ghritam) $[9,10]$. This study looks into the prospects of an Ayurvedabased polyherbal formulation, Jatyadi widely used in traditional medicine for chronic wounds (including diabetic wounds), ulcers, eczema, scalds, and burns healing as a topical application $[11,12]$. The pharmacopoeia version of Jatyadi (Jatyadi Ghritam), as in Ayurveda Formulary of India (AFI), consists of 11 herbs along with honey bee wax (Sikta) and copper sulfate (Tuttha) [10]. Jatyadi Thailam $\left(J T_{\mathrm{AFI}}\right)$ is also prepared in a sesame oil base instead of clarified butter as mentioned in the pharmacopoeia version of Jatyadi Ghritam, without changing the herbal ingredients. $J T_{\mathrm{AFI}}$ has shown significant clinical efficacy in healing diabetic wounds after application for 10 days, with a follow-up of 45 days showing no recurrence [13]. Another clinical case of acute erythroderma showed complete remission in lesions after three months of external application of $J T_{\mathrm{AFI}}$ along with other parenteral drugs [14]. A very preliminary attempt has been made to understand the mechanism of action of JT Thailam through healing in excision wound model in rats [15] and JT Ghritam in diabetes-induced rats [16]. Interestingly, there is another traditional version of this formulation, namely, Jatyadi Thailam ( $J T_{\mathrm{YG}}$ ) itself, which is used for similar indications in South India. The composition of this formulation $\left(J T_{\mathrm{YG}}\right)$ is different from $J T_{\mathrm{AFI}}$ and is referenced in the Yogagrantha text [17]. $J T_{Y G}$ is composed of 13 herbs fortified in coconut oil. The $J T_{\mathrm{YG}}$ formulation has not been evaluated using contemporary methods, even though it is used in clinical practice for healing chronic wounds [18].

The aim of this study was to evaluate the biological activities of hexane $\left(J T_{\mathrm{AFI}}-\mathrm{Hex}, J T_{\mathrm{YG}}-\mathrm{Hex}\right)$ and $90 \%$ ethanol $\left(J T_{\mathrm{AFI}}-\mathrm{EE}, J T_{\mathrm{YG}}-\mathrm{EE}\right)$ extracts of herbal fractions of $J T_{\mathrm{AFI}}$ and $J T_{\mathrm{YG}}$ formulations in vitro. Antibacterial study on $J T$ extracts was done through broth microdilution method to estimate its MICs against nine reference Gram (+) and Gram (-) bacterial strains and on clinical strains of MSSA, all involved in diabetic foot infection. The effects of plant extracts on proinflammatory cytokine and chemokine gene expression and protein secretion were examined using lipopolysaccharide(LPS-) stimulated human THP-1 macrophage cells as a model to understand the network of reactions at the molecular plane during the inflammatory phase of diabetic wounds.

\section{Materials and Methods}

2.1. Collection and Authentication of Plant Material. Fresh plant materials were collected in and around Palghat District, Kerala, India, and the dried herbs were collected from respective herb dealers across India. The samples were then authenticated at Fischer Herbarium (FRC) at the Institute of Forest Genetics and Tree Breeding, Coimbatore, recognised by the Royal Botanical Gardens of UK and certified by Dr. Kunjikanan. The specimens were deposited in the FRC with voucher numbers for all individual herbs, except Berberis aristata, covered from 24222 to 24242 . The details of the herbs and voucher numbers are summarized in Table 1 and Table 2. Berberis aristata root was identified based on the phytopharmacognostic method as stated in API [19].

2.2. Preparation of Plant Material and Extraction. All the plant materials were air-dried under shade and pulverized. $1000 \mathrm{~g}$ of both variants of $J T$ herb mixtures was sequentially extracted in $4 \mathrm{~L}$ of nonpolar solvent hexane (Hex) and polar solvent $90 \%$ ethanol (EE) for $6 \mathrm{~h}$ at room temperature by hot percolation method using Soxhlet apparatus. Hexane and 90\% ethanol extracts were concentrated up to $200 \mathrm{~mL}$ and $250 \mathrm{~mL}$, respectively, and subjected to qualitative and quantitative analysis for the phytochemical profile. The concentrated extracts were further evaporated, and EE extract was lyophilized to remove the last traces of the water. The obtained yields were $2.14 \%(\mathrm{w} / \mathrm{w})$ for $J T_{\mathrm{YG}}-\mathrm{Hex}, 3.58 \%(\mathrm{w} / \mathrm{w})$ for $J T_{\mathrm{YG}}-\mathrm{EE}$ (semisolid), $0.72 \%(\mathrm{w} / \mathrm{w})$ for $J T_{\mathrm{AFI}}-\mathrm{Hex}$, and $3.33 \%(\mathrm{w} / \mathrm{w})$ for $J T_{\mathrm{AFI}}-\mathrm{EE}$ (semisolid).

Stock solutions of $0.1 \mathrm{~g} / \mathrm{mL}$ of extracts with $90 \%$ of final DMSO concentration have been made for cell culture analysis and stock solutions of $0.5 \mathrm{~g} / \mathrm{mL}$ with $50 \%$ of final DMSO and $0.25 \%$ Tween 20 concentrations have been made for antibacterial studies.

2.3. Phytochemical Analysis of the JT Extracts. Extracts were tested initially for the presence of phytochemicals qualitatively according to standard methods such as precipitation or colouration tests as described by Evance [20] and further quantitative estimation was done only for the detected phytochemicals. Quantification of the total phenolic and tannin content of extracts was done by the Folin-Ciocalteu method according to [21, 22]. The concentrations of the phenols and tannins were estimated from gallic and tannic acids calibration curves, respectively. The aluminium chloride colorimetric method with a quercetin as a standard was used for the determination of the total flavonoid content of extracts as previously described [23]. The total anthocyanin content of extracts was determined by the $\mathrm{pH}$ differential method according to [24]. The Liebermann-Burchard test was used for determination of sterols, with cholesterol used as the standard as previously described [25]. The quantification of terpenoids, cardiac glycosides, and saponins was performed by gravimetric methods according to [26-28]. Quantitative determination of alkaloids and proteins was according to the methodology by Harborne [26] and Lowry [29]. 
TABLE 1: Herbal ingredients used for $J T_{\mathrm{YG}}$ preparation.

\begin{tabular}{|c|c|c|c|c|c|c|}
\hline $\begin{array}{l}\text { Specimens } \\
\text { No. }\end{array}$ & Botanical name & Family & $\begin{array}{l}\text { Vernacular } \\
\text { name }\end{array}$ & $\begin{array}{l}\text { Specimen Acc } \\
\text { No. }\end{array}$ & Part used & $\begin{array}{l}\text { Amount used of } \\
\text { herbs }\end{array}$ \\
\hline 1 & Aerva lanata (L.) Juss. & Amaranthaceae & Cherula & 24229 & $\begin{array}{l}\text { Whole } \\
\text { plant }\end{array}$ & 1 part \\
\hline 2 & $\begin{array}{c}\text { Calycopteris floribunda (Roxb.) } \\
\text { Lam. ex. Poir. }\end{array}$ & Combretaceae & Pullani & 24227 & leaf & 1 part \\
\hline 3 & Curcuma longa L. & Zingiberaceae & Manjal & 24235 & Rhizome & 1 part \\
\hline 4 & Cynodon dactylon (L.) Pers. & $\begin{array}{c}\text { Poaceae } \\
\text { (Graminae) }\end{array}$ & Arugampul & 24222 & $\begin{array}{l}\text { Whole } \\
\text { plant }\end{array}$ & 1 part \\
\hline 5 & $\begin{array}{c}\text { Erythrina variegate L. (= Erythrina } \\
\text { indica Lam.) }\end{array}$ & Fabaceae & Muruku & 24224 & Leaf & 1 part \\
\hline 6 & Glycyrrhiza glabra L. & Fabaceae & Erati mathuram & 24236 & Root & 1 part \\
\hline 7 & Jasminum flexile Vahl & Oleaceae & Jasmine & 24241 & Leaf & 1 part \\
\hline 8 & Murraya koenigii (L.) Spreng. & Rutaceae & Karuvepu & 24231 & Leaf & 1 part \\
\hline 9 & Nigella sativa L. & Ranunculaceae & Karujeeragam & 24242 & Seed & 1 part \\
\hline 10 & Oldenlandia corymbosa L. & Rubiaceae & Parpadagam & 24230 & $\begin{array}{l}\text { Whole } \\
\text { plant }\end{array}$ & 1 part \\
\hline 11 & Physalis minima L. & Solanaceae & Njotta & 24237 & $\begin{array}{l}\text { Whole } \\
\text { plant }\end{array}$ & 1 part \\
\hline 12 & Pupalia atropurpurea & Amaranthaceae & Cherukadaladi & 24238 & $\begin{array}{l}\text { Whole } \\
\text { plant }\end{array}$ & 1 part \\
\hline 13 & Vitex negundo L. & Lamiaceae & Karunochi & 24228 & Leaf & 1 part \\
\hline
\end{tabular}

TABLE 2: Herbal ingredients used for $J T_{\mathrm{AFI}}$ preparation.

\begin{tabular}{|c|c|c|c|c|c|c|}
\hline $\begin{array}{l}\text { Specimens } \\
\text { No. }\end{array}$ & Botanical name & Family & $\begin{array}{c}\text { Vernacular } \\
\text { name }\end{array}$ & $\begin{array}{c}\text { Specimen Acc } \\
\text { No. }\end{array}$ & Part used & $\begin{array}{c}\text { Amount used } \\
\text { of herbs }\end{array}$ \\
\hline 1 & Azadirachta indica A. Juss. & Meliaceae & Nimba & 24223 & Leaf & 1 part \\
\hline 2 & $\begin{array}{l}\text { Chrysopogon zizanioides (L.) Roberty } \\
\text { (Vetiveria zizanioides (L.) Nash) }\end{array}$ & $\begin{array}{c}\text { Poaceae } \\
\text { (Graminae) }\end{array}$ & Usira & 24233 & Root & 1 part \\
\hline 3 & Berberis aristata & Menispermaceae & Darvi & * & Stem & 1 part \\
\hline 4 & Curcuma longa L. & Zingiberaceae & Nisa & 24235 & Rhizome & 1 part \\
\hline 5 & Glycyrrhiza glabra L. & Fabaceae & Yastimadhu & 24236 & Root & 1 part \\
\hline 6 & $\begin{array}{c}\text { Hemidesmus indicus (L.) R. Br. ex. } \\
\text { Schult }\end{array}$ & Apocynaceae & Sariva (black) & 24234 & Root & 1 part \\
\hline 7 & Jasminum officinale Linn. & Oleaceae & Jati & 24241 & Leaf & 1 part \\
\hline 8 & Picrorhiza kurroa Royle ex. Benth & Plantaginaceae & Katuka & 24240 & $\begin{array}{l}\text { Root/ } \\
\text { rhizome }\end{array}$ & 1 part \\
\hline 9 & Pongamia pinnata (L.) Pierre & Fabaceae & Karanja & 24232 & Seed & 1 part \\
\hline 10 & Rubia cordifolia L. & Rubiaceae & Manjistha & 24225 & Root & 1 part \\
\hline 11 & Trichosanthes dioica Roxb. & Cucurbitaceae & Patola & 24419 & Leaf & 1 part \\
\hline
\end{tabular}

*Identified as per standards mentioned in API [19].

2.4. Gas Chromatography-Mass Spectrometry (GC-MS) Analysis. Four millilitres of $0.5 \mathrm{~N}$ methanolic sodium hydroxide was added to the $150 \mathrm{mg}$ of JT-Hex extracts and heated on a steam bath until the fat globules went into solution. After $5 \mathrm{~min}, 5 \mathrm{~mL}$ of BF3-methanol was added to the flask and the mixture was boiled for $2 \mathrm{~min}$. A saturated sodium chloride solution was added to the flask to float the methyl esters. They were transferred with a syringe to a separatory funnel and $20 \mathrm{~mL}$ of petroleum ether (b.p. $30-60^{\circ} \mathrm{C}$ reagent grade redistilled) was added. The layers were separated by $1 \mathrm{~min}$ vigorous shaking. The petroleum ether layer was drained through filter paper and the solvent was then evaporated on a $60^{\circ} \mathrm{C}$ water bath. A $1 \mathrm{~mL}$ aliquot ester of the $J T$-Hex extracts was subjected to analysis by GC-MS.

GC-MS analysis was conducted on an Agilent 7890A GC coupled with a 5975 mass selective detector (Agilent
Technologies, USA). Samples were separated on a DB-5MS capillary column (30 m length $x 0.25 \mathrm{~mm}$ diameter $x 0.25 \mu \mathrm{m}$ film thickness). The oven temperature was held at $40^{\circ} \mathrm{C}$ for $5 \mathrm{~min}$ and raised to $280^{\circ} \mathrm{C}$ at a rate $5^{\circ} \mathrm{C} / \mathrm{min}$. Pure helium was used as a carrier gas at a constant flow rate of $1 \mathrm{~mL} / \mathrm{min}$. Diluted samples in methanol of $3 \mu \mathrm{L}$ were injected in the split mode with a split ratio of $50: 1$. The chemical composition of the extracts was identified from the chromatograms and mass spectra using the database of NIST08 Library.

2.5. Bacterial Strains. The following reference and clinical bacterial strains were used in this study: S. aureus ATCC 25923, S. aureus (MRSA) ATCC 33592, S. epidermidis RP62 A, Enterococcus faecalis 29212, Escherichia coli ATCC 25922, Pseudomonas aeruginosa ATCC 27853, multidrug- 
resistant (MDR) P. aeruginosa ATCC BAA-2108, Proteus mirabilis ATCC 29245, and Klebsiella pneumoniae ATCC 33495. All the reference strains were obtained from the microbiology laboratory at Riga East University Hospital (REUH). The microorganisms were revived for bioassay by subculturing in fresh nutrition Trypticase soy broth for $24 \mathrm{~h}$ before use. The clinical material was collected by a sterile cotton swab from diabetic foot ulcers from DFI patients admitted to REUH. Collection of clinical samples from diabetic foot wounds for bacterial isolates was approved by the ethics committee at the Institute of Cardiovascular and Regenerative Medicine, University of Latvia. Four S. aureus cultures were isolated and identified microbiologically up to a species level at the REUH microbiology laboratory using the BBL Crystal system (Becton, Dickinson, UK). Susceptibility to a panel of antimicrobials was tested according to Clinical and Laboratory Standard Institute guidelines [30] by the agar disk diffusion test and the E-test using Mueller-Hinton $(\mathrm{MH})$ agar (Becton Dickinson, UK) against the following panel of antibacterials: penicillin, gentamicin, cefazolin, erythromycin, clindamycin, vancomycin, ciprofloxacin, and trimethoprim-sulfamethoxazole. Methicillin resistance was tested by a cefoxitin disk on an agar screen plate. Plates inoculated with clinical S. aureus cultures were incubated for 20-24h. The antibiogram of four S. aureus strains showed susceptibility to methicillin (cefoxitin).

2.6. Broth Microdilution Method. The antibacterial efficacy of the JT extracts was tested by determining the minimum inhibitory concentration (MIC) by broth microdilution method as described by Balouiri [31] with modifications. Stock solutions of gentamicin $(0.4 \mathrm{mg} / \mathrm{mL})$ and streptomycin $(1 \mathrm{mg} /$ $\mathrm{mL}$ ) were used as MIC controls in each experiment according to CLSI standards CLSI-2017-M02-A12 [30]. Unsupplemented $\mathrm{MH}$ broths with and without the bacterial inoculate were used as positive and negative controls, respectively, in each experiment. DMSO was used as vehicle control for the inhibitory effect on all bacterial strains. The twofold dilution series of diluent DMSO were made in each well (starting from $12.5 \%$ in the first well, $6.25 \%$ in the second well, and so forth). The concentration of DMSO at $6.25 \%$ in the second well was below the toxic level as tested separately and did not inhibit the growth of bacteria.

Twofold dilution series of each extract were prepared in $\mathrm{MH}$ broth (starting from a concentration of $250 \mathrm{mg} / \mathrm{mL}$ ) and added to 96 -well microtiter plate $(100 \mu \mathrm{L} /$ well $)$. Overnight grown fresh bacterial cells were suspended in sterile saline and adjusted to a turbidity of McFarland standard No 0.5, bacterial cell suspension containing $1.5 \times 10^{8}$ colony-forming units $(\mathrm{CFU} / \mathrm{mL})$. The bacterial cell suspension was further diluted 1:100 in distilled water and aliquoted into a microplate $100 \mu \mathrm{L}$ per well. To calculate MIC, after $20 \mathrm{~h}$ of incubation at $35^{\circ} \mathrm{C}, 10 \mu \mathrm{L}$ aliquots of the appropriate dilution were withdrawn from the microtiter plate and inoculated on $\mathrm{MH}$ agar in a Petri dish and incubated for $24 \mathrm{~h}$. Colonyforming units of each dilution were counted and compared to the control Petri dish inoculated $24 \mathrm{~h}$ earlier with $10 \mu \mathrm{L}$ of the same strain suspension for MIC determination. The MIC value was calculated manually and assumed the same as minimum bactericidal concentration when $99.9 \%$ inhibition of bacterial growth after inoculation in a Petri dish was observed [31]. Each extract was tested in triplicate for statistical reliability.

2.7. Cell Culture and Differentiation Induction. The human THP-1 monocyte cell line was obtained from ATCC (American Type Culture Collection). THP-1 cells were maintained in RPMI-1640 medium containing 10\% fetal bovine serum and antibiotics and incubated in $5 \% \mathrm{CO}_{2}$ at $37^{\circ} \mathrm{C}$. THP-1 monocytes were stimulated to differentiate into macrophages with phorbol 12-myristate 13-acetate (PMA) $(20 \mathrm{ng} / \mathrm{mL})$ for $24 \mathrm{~h}$. Medium was exchanged for PMA-free medium for $48 \mathrm{~h}$ before cells were used for experiments.

2.8. Cell Viability Testing. Cell viability was tested by Cell Counting Kit-8 (CCK-8) (Sigma-Aldrich, USA), according to the manufacturer's instructions. THP-1 cells $(100 \mu \mathrm{L})$ were seeded into a 96-well tissue culture plate at the density of $10^{4}$ cells per well and grown in the presence or absence of various concentrations $(3-200 \mu \mathrm{g} / \mathrm{mL})$ of $J T$ plant extracts. Wells with dead THP-1 cells were used as the negative control wells. CCK-8 solution $(10 \mu \mathrm{L})$ was added to the cells at 24 and $48 \mathrm{~h}$ and plates were incubated for $1 \mathrm{~h}$ at $37^{\circ} \mathrm{C}$. The absorbance of each well was measured at $450 \mathrm{~nm}$ using a microplate reader Victor $3^{\mathrm{TM}}$ (Perkin Elmer, USA). Wells without cells but containing medium were used as a blank value that was subtracted from all values. Each assay was performed in triplicate.

2.9. RNA Extraction and Quantitative Real-Time Polymerase Chain Reaction ( $q R T-P C R)$. Total RNA was isolated from cultured cells using TRIzol reagent (Sigma, USA), according to the manufacturer's protocol. First-strand cDNA was synthesized from $2 \mu \mathrm{g}$ RNA using oligo (dT) primers with Revert Aid H Minus kit (Thermo Fisher Scientific, USA). qRT-PCR was performed using Absolute Blue SYBR green Master Mix reagent (Thermo Fisher Scientific, USA) with a ViiA7 real-time PCR detection system (Applied Biosystems, USA). The primer pairs used for the gene amplifications are listed in Table 3 mRNA levels were quantified and normalized to levels of reference gene RPS29 using the $2^{-\Delta \Delta C t}$ method and presented as relative expression compared with values of untreated cells.

2.10. Quantification of Cytokines and Chemokines. Conditioned media were obtained from untreated and JT extract-treated THP-1 macrophages. The concentrations of the IL-6, IL-1 $\beta$, MCP-1, and CXCL10 biomolecules were measured by Luminex Multiplex immunoassay (R\&D Systems, USA) according to the manufacturer's instructions and analyzed on a Luminex 200 (Luminex Corporation, USA). At least three independent repetitions in duplicate were made per sample. Concentrations of the analytes were quantified with five parameters logistic (5-PL) curve fit and expressed in $\mathrm{pg} / \mathrm{mL}$. 
TABLE 3: Sequences for qRT-PCR primers used in this study.

\begin{tabular}{lcc}
\hline $\begin{array}{l}\text { Primer } \\
\text { name }\end{array}$ & Sequence $\left(5^{\prime}-3^{\prime}\right)$ & $\begin{array}{c}\text { Product } \\
\text { length, bp }\end{array}$ \\
\hline IL-6 Fw & AGACAGCCACTCACCTCTTCAG & 132 \\
IL-6 Rv & TTCTGCCAGTGCCTCTTTGCTG & \\
\hline IL-1 $\beta$ Fw & CCACAGACCTTCCAGGAGAATG & 131 \\
IL-1 $\beta$ Rv & GTGCAGTTCAGTGATCGTACAGG & \\
\hline TNF- $\alpha$ Fw & CCCAGGGACCTCTCTCTAATCA & \multirow{2}{*}{116} \\
TNF- $\alpha$ Rv & AGCTGCCCCTCAGCTTGAG & \\
\hline MCP-1 Fw & AGAATCACCAGCAGCAAGTGTCC & \multirow{2}{*}{98} \\
MCP-1 Rv & TCCTGAACCCACTTCTGCTTGG & \\
\hline CXCL10 & GGTGAGAAGAGATGTCTGAATCC & \multirow{2}{*}{134} \\
Fw & & \\
CXCL10 & GTCCATCCTTGGAAGCACTGCA & \\
Rv & & \\
\hline $\begin{array}{l}\text { RPS29 Fw } \\
\text { RPS29 Rv }\end{array}$ & CAAGATGGGTCACCAGCAG & \multirow{2}{*}{ ATATTCCGGATCAGACCGT } \\
\hline
\end{tabular}

2.11. Statistical Analysis. Statistical analysis of MIC data was done using chi-square test. The median value for each MIC was calculated. Gene expression results are expressed as mean\pm standard deviation (SD) of the indicated number of experiments. Student's $t$-test was used to assess the statistical significance of differences. Significant differences were assumed for $p<0.05$. The statistical analysis was performed using GraphPad Prism 5.0 software (GraphPad Software Inc, USA).

\section{Results}

3.1. Phytochemical Evaluation of JT Extracts. The quantitative phytochemical screening of obtained JT plant extracts revealed the presence of phenols, proteins, tannins, sterols, and terpenoids in $J T_{\mathrm{YG}}-\mathrm{EE}, J T_{\mathrm{AFI}}-\mathrm{EE}$, and $J T_{\mathrm{AFI}^{-}}-\mathrm{Hex}$ extracts, as shown in Table 4. All JT extracts had flavonoids with the highest content in $J T_{\mathrm{YG}_{\mathrm{G}}}$-EE extract. Both $J T_{\mathrm{YG}-\mathrm{EE}}$ and $J T_{\mathrm{AFI}} \mathrm{EE}$ were rich in proteins. Alkaloids were detected only in $J T_{\mathrm{AFI}}-\mathrm{EE}$ and saponins only in $J T_{\mathrm{YG}}-\mathrm{EE}$ extracts. Glycosides were found to be present only in hexane extracts of both JT formulations with the higher concentration in $J T_{\mathrm{YG}}-\mathrm{Hex}$. Anthocyanins were present only in $J T_{\mathrm{YG}}$ extracts. Overall, JT-EE extracts had a higher content in phenols, proteins, tannins, sterols, and flavonoids.

3.2. Chemical Composition of JT Extracts. The presence of chemical components in the JT hexane extracts was analyzed

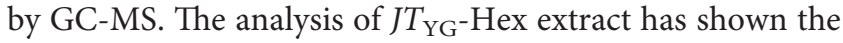
presence of 36 peaks in the gas chromatogram and 21 components corresponding to the major peaks have been determined and are listed in Table 5. Major chemical compounds were 9,12-octadecadienoic acid or linoleic acid (24.86\%), n-hexadecanoic acid or palmitic acid (17.17\%), cis 13- octadecenoic acid (15.19\%), cis-13,16-docosadienoic acid (5.29\%), ar-turmerone (2.49\%), alpha-turmerone $(2.03 \%)$, beta-turmerone or curlone $(1.84 \%)$, 9-octadecenoic acid (Z) methyl ester or oleic acid (1.46\%), phytol (1.61\%), and squalene $(1.84 \%)$, while other compounds were present in minor quantities with peak areas ranging from 0.09 to $1.61 \%$.
TABLE 4: Quantitative phytochemical evaluation of the JT extracts.

\begin{tabular}{|c|c|c|c|c|}
\hline \multirow{2}{*}{ Phytochemical (\%) } & \multicolumn{4}{|c|}{ Extracts } \\
\hline & $J T_{\mathrm{YG}_{\mathrm{G}}}-\mathrm{Hex}$ & $J T_{\mathrm{YG}}-\mathrm{EE}$ & $J T_{\mathrm{AFI}}-\mathrm{Hex}$ & $J T_{\mathrm{AFI}}-\mathrm{EE}$ \\
\hline Alkaloids & $-{ }^{a}$ & - & - & 6.17 \\
\hline Phenols & - & 6.20 & 4.60 & 8.28 \\
\hline Proteins & 1.40 & 11.56 & 4.32 & 12.96 \\
\hline Tannins & - & 9.80 & 5.69 & 14.32 \\
\hline Sterols & - & 11.30 & 9.80 & 4.02 \\
\hline Glycosides & 16.70 & - & 2.82 & - \\
\hline Saponins & - & 11.04 & - & - \\
\hline Terpenoids & - & 17.16 & 18.51 & 9.93 \\
\hline Flavonoids & 3.06 & 9.02 & 2.70 & 5.26 \\
\hline Anthocyanins & 0.19 & 0.50 & - & - \\
\hline
\end{tabular}

${ }^{a}$ Quantitative evaluation of phytochemicals was not done as preliminary qualitative tests showing absence of these phytochemicals.

Gas chromatogram analysis of $J T_{\mathrm{AFI}}-\mathrm{Hex}$ extract revealed 33 distinct peaks and the 25 components corresponding to the major peaks have been determined and listed in Table 6. Major chemical compounds were 6-octadecenoic acid (27.36\%), n-hexadecanoic acid (10.17\%), 3dibenzofuranamine (13.24\%), octadecane (5.67\%), fumaric acid, 2, 4-dimethyl pent-3-yl isohexyl ester (5.36\%), fumaric,3,5-dichlorophenyl isohexyl ester (4.99\%), 9,12-octadecadienoic acid (Z, Z) (3.12\%), and phytol (2.23\%), while other compounds were present in minor quantities with peak areas ranging from 0.321 to $.97 \%$.

3.3. Antibacterial Activity of JT Extracts on Reference Bacterial Strains. The antibacterial properties of JT extracts were elucidated on four Gram (+) (S. aureus ATCC 25923, MRSA ATCC 33592, S. epidermidis RP62 A, and E. faecalis 29212) and five Gram (-) (E. coli ATCC 25922, P. aeruginosa ATCC 27853, MDR P. aeruginosa ATCC BAA-2108, P. mirabilis ATCC 29245, and K. pneumoniae ATCC 33495) reference bacterial strains. The results of MIC as determined by broth microdilution method are shown in Table 7 . In general, MIC values ranged from 1.95 to $62.5 \mathrm{mg} / \mathrm{mL}$. The extracts at bactericidal concentrations higher than $125 \mathrm{mg} /$ $\mathrm{mL}$ were considered as having no inhibition since the bacterial growth was influenced by the diluent $12.5 \%$ DMSO.

All JT extracts showed better inhibitory activity for Gram (+) bacteria compared to Gram (-) (Table 7). When the cases of inhibition (MIC determined) were compared to the cases without inhibition, $100 \%$ of Gram (+) and only $40 \%$ of Gram (-) bacterial strains had cases of inhibition by extracts studied. Both $J T_{\mathrm{YG}}-\mathrm{Hex}$ and $J T_{\mathrm{YG}}-\mathrm{EE}$ extracts showed lower MIC for Gram (+) bacterial reference strains (median 11.7) than MIC for Gram (-) strains (median $\geq 125.0$ ). Similarly, both $J T_{\mathrm{AFI}}-\mathrm{EE}$ and $J T_{\mathrm{AFI}}-\mathrm{Hex}$ extracts were also more active against Gram (+) (median 31.25) compared to MIC for Gram (-) (median 93.75) reference strains. The overall efficacy of $J T_{\mathrm{YG}}$ formulation extracts (median 11.7) was higher than that of $J T_{\mathrm{AFI}}$ formulation extracts (median 31.25).

In order to investigate the best efficacy for Gram (+) bacteria, the MICs were further compared between the extracts. The lowest MIC was detected for biofilm-forming S. epidermidis RP62 A strain by $J T_{\mathrm{YG}}-\mathrm{EE}$ and $J T_{\mathrm{YG}}-\mathrm{Hex}$ 
TABLE 5: Biologically active chemical compounds of $J T_{\mathrm{YG}}-\mathrm{Hex}$ extract.

\begin{tabular}{lccc}
\hline S. No. & Retention time, min & Active components & Peak area, \% \\
\hline 1 & 42.529 & Ar-Turmerone & 2.49 \\
2 & 42.767 & Turmerone & 2.03 \\
3 & 44.349 & Curlone (beta-turmerone) & 1.84 \\
4 & 45.518 & Bicyclo (3.1.1) heptanes,6,6-dimethyl-2methylene-(1S) & 0.09 \\
5 & 46.128 & Bicyclo (2.2.1) heptan-2-ol,1,7,7-trimethyl-acetate & 0.18 \\
6 & 45.827 & Cyclohexane carboxylic acid, dimethyl phenyl ester & 0.60 \\
7 & 46.548 & $2,6,6$-trimethylbicyclo (3.1.1) hepatane & 0.57 \\
8 & 46.606 & 2-Hexadecane,3,7,11,15-tetramethyl-(R-R*, $\mathrm{R}^{*}$-(E)) & 0.21 \\
9 & 46.775 & 3-Tetradecyne & 0.19 \\
10 & 47.311 & Hexadexanoic acid methyl ester & 0.16 \\
11 & 47.502 & Cyclotetradecane & 0.57 \\
12 & 47.790 & n-Hexadecanoic acid & 17.17 \\
13 & 48.411 & Phytol & 1.61 \\
14 & 48.674 & 9,12-Octadecadienoic acid (Z, Z) & 24.86 \\
15 & 48.847 & cis-13-Octadecadienoic acid & 15.19 \\
16 & 49.484 & cis-13,16-Docasadienoic acid & 5.29 \\
17 & 50.042 & 1 H- Indole & 1.19 \\
18 & 50.226 & Imidazole,1-(9-borabicyclo (3.1.1) non-9-yl) & 1.08 \\
19 & 50.306 & Squalene & 1.51 \\
20 & 52.295 & Tetracosane & 1.84 \\
21 & 53.065 & Hexadecanoic acid,2-hydroxy-1-(Hydroxymethyl) ethyl ester & 0.57 \\
\hline
\end{tabular}

TABLE 6: Biologically active chemical compounds of $J T_{\mathrm{AFI}^{-}}$Hex extract.

\begin{tabular}{|c|c|c|c|}
\hline S. No. & Retention time, min & Active components & Peak area $\%$ \\
\hline 1 & 42.509 & Ar-Turmerone & 0.85 \\
\hline 2 & 42.748 & Turmerone & 0.35 \\
\hline 3 & 44.348 & Curlone (beta-turmerone) & 0.52 \\
\hline 4 & 46.555 & Bicyclo (3.1.1) heptanes,6,6-dimethyl-,(1.alpha.,2.beta.,5.alpha) & 0.32 \\
\hline 5 & 47.686 & n-Hexadecanoic acid & 10.17 \\
\hline 6 & 47.985 & Cyclopentene,1-pentyl & 0.89 \\
\hline 7 & 48.060 & 1,19-Eicosadiene & 1.09 \\
\hline 8 & 48.412 & Phytol & 2.23 \\
\hline 9 & 48.669 & 6-Octadecanoic acid & 27.36 \\
\hline 10 & 49.086 & 3-Dibenzofuranamine & 13.24 \\
\hline 11 & 49.435 & Fumaric acid, 2, 4-dimethyl pent-3-yl isohexyl ester & 5.36 \\
\hline 12 & 49.503 & Fumaric,3,5-dichlorophenyl isohexyl ester & 4.99 \\
\hline 13 & 49.666 & Hentriacontane & 5.67 \\
\hline 14 & 50.124 & Cis-13 = octadecenoic acid, methyl ester & 1.16 \\
\hline 15 & 50.258 & Bezzoic anhyide, 4,4',6,6'- Tetramethoxy $-2,2^{\prime}$-dimethyl & 2.68 \\
\hline 16 & 50.428 & Benzaldehyde, 6-Hydroxy-4-methoxy-2,3-dimethyl & 1.65 \\
\hline 17 & 50.573 & 4H-Pyran-4-one-2,6-diethyl-3,5-diemthyl & 1.46 \\
\hline 18 & 50.877 & 1-H-Imidazole-5-carboxamde,4-bebzoyl-N-(2-Pyridyl) & 1.08 \\
\hline 19 & 51.032 & Lycopodan-5-1,12 hydroxy-15-methyl,(15 R)- & 2.64 \\
\hline 20 & 51.177 & 2,6-Dihydroxynaphthalene & 1.97 \\
\hline 21 & 51.335 & Cylcopropaneoctanal,2-octyl- & 1.00 \\
\hline 22 & 51.438 & 9,12-Octadecadienoic acid $(\mathrm{Z}, \mathrm{Z})$ & 3.12 \\
\hline 23 & 52.292 & $2,6,10,14,18,22$-Tetracosahexane & 2.34 \\
\hline 24 & 52.778 & Stigmasterol & 1.21 \\
\hline 25 & 53.072 & Tetracosane & 0.82 \\
\hline
\end{tabular}

extracts $(1.95 \mathrm{mg} / \mathrm{mL})$ followed by $J T_{\mathrm{AFI}^{-}}-\mathrm{EE}$ extract $(15.6 \mathrm{mg} / \mathrm{mL})$ and by $J T_{\mathrm{AFI}}-\mathrm{Hex}(31.25 \mathrm{mg} / \mathrm{mL})$, as shown in Table 7. Notably, the results indicated that all four extracts were active against MRSA ATCC 33592 strain, with the highest inhibitory activity shown by $J T_{\mathrm{YG}}-\mathrm{EE}$ and $J T_{\mathrm{AFI}}-\mathrm{EE}$ extracts $(15.6 \mathrm{mg} / \mathrm{mL})$ (Table 7$)$.

Further, the overall inhibitory efficacy for Gram (+) and Gram (-) bacteria was compared between the extracts. Gram
(-) bacteria were susceptible only to EE extracts, except for $P$. aeruginosa MDR ATCC BAA-2108. There was no significantly important difference $(p=0.527)$ in the frequency of inhibition between $J T_{\mathrm{YG}}-\mathrm{EE}$ (median 31.25) and $J T_{\mathrm{YG}^{-}}$ Hex (median 62.5). There was also no significantly important difference $(p=0.836)$ in the frequency of inhibition between $J T_{\mathrm{AFI}}-\mathrm{EE}$ (median 62.52) and $J T_{\mathrm{AFI}}-\mathrm{Hex}$ (median $\geq 125$ ), between $J T_{\mathrm{YG}}-\mathrm{EE}$ (median 31.25 ) and $J T_{\mathrm{AFI}-\mathrm{EE}}$ 
TABLE 7: MIC values of JT extracts against reference bacterial strains.

\begin{tabular}{|c|c|c|c|c|c|c|c|}
\hline \multicolumn{8}{|c|}{$\mathrm{MIC}, \mathrm{mg} / \mathrm{mL}^{a}$} \\
\hline Reference bacterial strains & Gram $( \pm)$ & $\begin{array}{c}J T_{\mathrm{YG}^{-}} \\
\mathrm{EE}\end{array}$ & $\begin{array}{c}J T_{\mathrm{YG}^{-}} \\
\mathrm{Hex}\end{array}$ & $\begin{array}{c}J T_{\mathrm{AFI}^{-}} \\
\mathrm{EE}\end{array}$ & $\begin{array}{c}J T_{\mathrm{AFI}^{-}} \\
\mathrm{Hex}\end{array}$ & Gentamicin control & Streptomycin control \\
\hline S. aureus ATCC 25923 & + & 7.81 & 7.81 & 15.60 & 31.25 & $\leq 0.0156$ & 0.0019 \\
\hline MRSA ATCC $33592^{\mathrm{b}}$ & + & 15.60 & 31.25 & 15.60 & 31.25 & $\mathrm{ND}^{\mathrm{c}}$ & ND \\
\hline S. epidermidis RP62 A & + & 1.95 & 1.95 & 15.60 & 31.25 & 0.012 & $\leq 0.0780$ \\
\hline E. faecalis ATCC 29212 & + & 31.25 & 62.50 & 62.50 & $\mathrm{NI}^{\mathrm{d}}$ & 0.0039 & 0.0048 \\
\hline E. coli ATCC 25922 & - & 62.50 & $\mathrm{NI}$ & 31.25 & NI & 0.0015 & 0.0039 \\
\hline P. aeruginosa ATCC 27853 & - & 15.60 & NI & 62.50 & NI & 0.2500 & 0.0078 \\
\hline P. aeruginosa MDR ATCC BAA-2108 & - & NI & 62.5 & 62.50 & NI & ND & ND \\
\hline P. mirabilis ATCC 29245 & - & NI & NI & NI & NI & $\leq 0.00003$ & 0.0780 \\
\hline K. pneumoniae ATCC 33495 & - & 62.50 & $\mathrm{NI}$ & 62.50 & $\mathrm{NI}$ & $\leq 0.0007$ & 0.0004 \\
\hline
\end{tabular}

${ }^{a}$ MICs were determined by broth microdilution method and all experiments were done in triplicate; ${ }^{b} \mathrm{MICs}$ were determined as $0.125 \mu \mathrm{g} / \mathrm{mL}$ to ciprofloxacin and $1.5 \mu \mathrm{g} / \mathrm{mL}$ to vancomycin; ${ }^{\mathrm{c}} \mathrm{ND}$ : not determined; ${ }^{\mathrm{d}} \mathrm{NI}$ : no inhibition; ${ }^{\mathrm{e}} \mathrm{MICs}$ were determined as $>32 \mu \mathrm{g} / \mathrm{mL}$ to imipenem and ciprofloxacin.

(median 31.25), and between $J T_{\mathrm{YG}}-\mathrm{Hex}$ (median 62.5) and $J T_{\mathrm{AFI}^{-}}$Hex extract (median 62.5) (Table 7).

3.4. Antibacterial Activity of JT Extracts on Clinical S. aureus Strains. Additionally, four S. aureus clinical strains, namely, 704, 526, 250, and 588, isolated from DFIs, were examined for antibacterial activity by broth microdilution method. The results of MICs are shown in Table 8 . The values of MIC varied from 1.95 to $62.5 \mathrm{mg} / \mathrm{mL}$ among clinical strains and among extracts, except for $J T_{\mathrm{YG}}-\mathrm{Hex}$ extract $(7.81 \mathrm{mg} / \mathrm{mL})$. There was no difference in MIC between $J T_{\mathrm{YG}}$-EE (median 15.6) and $J T_{\mathrm{AFI}}-\mathrm{EE}$ (median 15.6) extracts and, similarly, between $J T_{\mathrm{YG}_{\mathrm{G}}}-\mathrm{Hex}$ (median 62.5) and $J T_{\mathrm{AFI}}-\mathrm{Hex}$ extracts (median 62.5), with the EE extracts showing higher activity compared to that of Hex extracts. Our data showed that the frequency of inhibition was not significantly different between $S$. aureus clinical strains and the reference group $(p=0.590)$.

As a component of the original $J T_{\mathrm{AFI}}$ formulation, possessing antibacterial potential on the skin, the inhibitory effect of copper sulfate was additionally tested on S. aureus clinical strains by broth microdilution method. Copper sulfate stock solution was prepared at a concentration of $3.53 \mathrm{mg} / \mathrm{mL}$, which is equal to that used in the original $J T_{\mathrm{AFI}}$ product (10.6 g/3 L of water). Our data indicate that MIC was achieved by copper sulfate already at concentration $0.88 \mu \mathrm{g} /$ $\mathrm{mL}$, which is much lower than the concentration in the original $J T_{\text {AFI }}$ product (Table 8 ).

3.5. Effects of JT Plant Extracts on Cell Viability. The effects of JT extracts on the viability of THP-1 macrophages were examined to determine the concentrations of the extracts that are nontoxic for the cells. As can be seen from Figure 1, no cytotoxic effect was observed following a 24 and $48 \mathrm{~h}$ treatment of the cells with both the $J T_{\mathrm{YG}}-\mathrm{Hex}$ and $J T_{\mathrm{AFI}}-\mathrm{Hex}$ at concentrations less than $50 \mu \mathrm{g} / \mathrm{mL}$ and the $J T_{\mathrm{YG}}-\mathrm{EE}$ and $J T_{\mathrm{AFI}^{-}} \mathrm{EE}$ at concentrations less than $12 \mu \mathrm{g} / \mathrm{mL}$. Therefore, for subsequent experiments, concentrations of $50 \mu \mathrm{g} / \mathrm{mL}$ for $J T_{\mathrm{YG}}-\mathrm{Hex}$ and $J T_{\mathrm{AFI}}-\mathrm{Hex}$ and $10 \mu \mathrm{g} / \mathrm{mL}$ for $J T_{\mathrm{YG}}-\mathrm{EE}$ and $J T_{\mathrm{AFI}^{-}} \mathrm{EE}$ were used to induce a maximal response without causing cell toxicity. Exposure to vehicle control DMSO ranging from 0.2 to $0.003 \%$ had no effect on cell viability (data not shown).

3.6. JT Extracts Suppresses Gene Expression of Inflammatory Cytokines and Chemokines in THP-1 Macrophages. We quantified the expression levels of the proinflammatory cytokines IL-6, IL- $1 \beta$, TNF- $\alpha$, and chemokines-MCP- 1 and CXCL10, which are chemoattractant factors involved in monocyte/macrophage and T-cell recruitment. THP-1 macrophages were stimulated with LPS $(1 \mu \mathrm{g} / \mathrm{mL})$ with or without the addition of various concentrations of JT-Hex (50,10, and $1 \mu \mathrm{g} / \mathrm{mL}$ ) and $J T$-EE (10 and $1 \mu \mathrm{g} / \mathrm{mL})$ plant extracts. Expression of each molecule at mRNA level was upregulated after $4 \mathrm{~h}$ stimulation with LPS in THP-1 macrophages (Figure 2). All extracts in a dose-dependent manner showed the most potent inhibition of IL-6, CXCL10 and MCP-1 gene expression. The addition of $J T_{\mathrm{YG}_{\mathrm{G}}}-\mathrm{Hex}$ at 50,10 , and $1 \mu \mathrm{g} / \mathrm{ml}$ resulted in significant reduction of LPS- stimulated IL-6 mRNA levels by 95\%, 84\% $(p<0.0001), 22 \%$ $(p=0.0019)$, CXCL10 mRNA levels by $95 \%(p<0.0001), 61 \%$ $(p=0.0006)$, and $21 \%(p=0.005)$ and MCP-1 levels by $81 \%$ $(p<0.0001), 60 \%(p=0.005)$, and 11\% ( $p=0.096)$, respectively (Figures 2(a) and 2(d)). The addition of $J T_{\mathrm{AFI}}-\mathrm{Hex}$ at 50, 10 and $1 \mu \mathrm{g} / \mathrm{mL}$ resulted in significant reduction of LPSstimulated IL-6 mRNA levels by $92 \%(p<0.0001), 66 \%$ $(p=0.0003)$, and 28\% ( $p=0.009)$, CXCL10 mRNA levels by 92\% $(p<0.0001), 54 \%(p=0.001)$, and 34\% $(p=0.002)$ and MCP-1 levels by 74\%, 44\% ( $p<0.0001)$, and 15\% $(p=0.062)$, respectively (Figures $2(\mathrm{a})$ and $2(\mathrm{~d})$ ). The addition of $J T_{\mathrm{YG}}-\mathrm{EE}$ at 10 and $1 \mu \mathrm{g} / \mathrm{mL}$ resulted in significant reduction of LPSstimulated IL-6 mRNA levels by $95 \%$ and $51 \%(p<0.0001)$, CXCL10 mRNA levels by $94(p<0.0001)$ and $30 \%(p=0.003)$ and MCP-1 levels by 56\% $(p=0.0002)$ and $22 \%(p=0.011)$, respectively (Figures $2(\mathrm{a})$ and $2(\mathrm{~d})$ ). The addition of $J T_{\mathrm{AFI}^{-} \mathrm{EE}}$ at 10 and $1 \mu \mathrm{g} / \mathrm{mL}$ resulted in significant reduction of LPSstimulated IL- 6 mRNA levels by $80 \%(p<0.0001)$ and $20 \%$ $(p=0.004)$, CXCL10 mRNA levels by 74\% $(p<0.0001)$ and $10 \%(p=0.058)$ and MCP-1 levels by $24 \%(p=0.001)$ and $3 \%$ $(p=0.069)$, respectively (Figures $2(\mathrm{a})$ and $2(\mathrm{~d}))$. A significant $65 \%(p=0.0004)$ and $43 \%(p=0.005)$ decrease in IL-1 $\beta$ mRNA and $72 \%(p<0.0001)$ and $36 \%(p=0.008)$ decrease in TNF- $\alpha$ mRNA was detectable at $50 \mu \mathrm{g} / \mathrm{mL}$ for $J T_{\mathrm{YG}-\mathrm{Hex} \text { and }}$ 
TABLE 8: MIC values of JT extracts against clinical isolates of $S$. aureus.

$$
\mathrm{MIC}, \mathrm{mg} / \mathrm{mL}^{a}
$$

Clinical isolates, $S$. aureus $J T_{\mathrm{YG}^{-}} \mathrm{EE} \quad J T_{\mathrm{YG}^{-}} \mathrm{Hex} \quad J T_{\mathrm{AFI}^{-}} \mathrm{EE} \quad J T_{\mathrm{AFI}^{-}}$Hex Gentamicin control Streptomycin control Copper sulfate

\begin{tabular}{lccccccc}
\hline 704 & 1.95 & 7.81 & 7.81 & 62.50 & $\leq 0.0015$ & $\leq 0.0004$ & 0.00088 \\
526 & 7.81 & 7.81 & 15.60 & 31.25 & $\leq 0.0015$ & $\leq 0.0004$ & 0.00088 \\
250 & 15.60 & 7.81 & 15.60 & 62.50 & $\leq 0.0015$ & 0.0078 & 0.00088 \\
588 & 31.25 & 7.81 & 15.60 & 31.25 & $\leq 0.0015$ & 0.0039 & 0.00088 \\
\hline
\end{tabular}

${ }^{a}$ - MICs were determined by broth microdilution method and all experiments were done in triplicate.

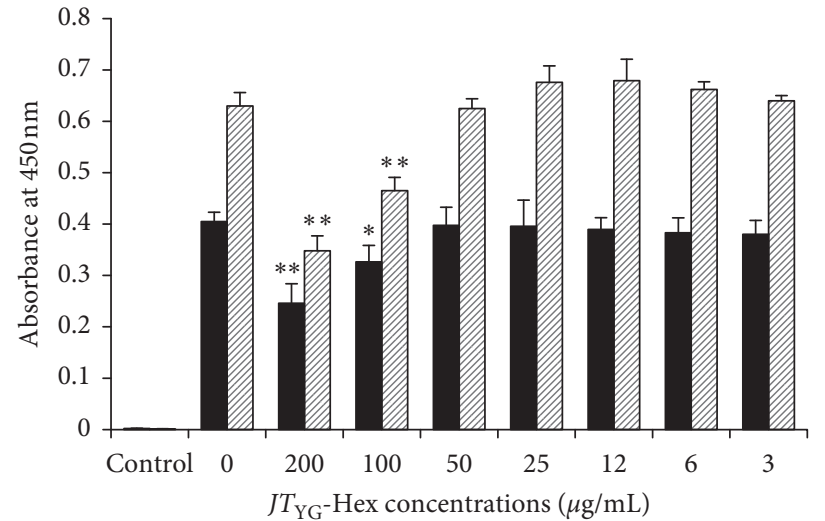

- $24 \mathrm{~h}$

๒ $48 \mathrm{~h}$

(a)

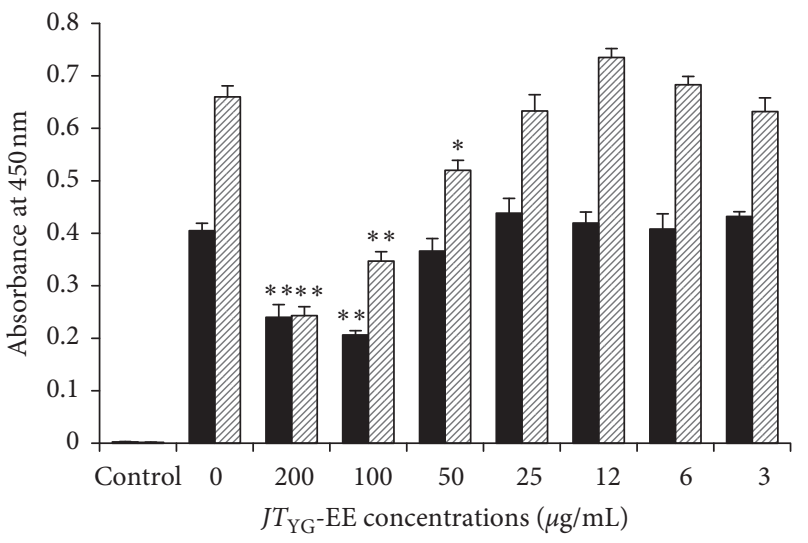

- $24 \mathrm{~h}$

四 $48 \mathrm{~h}$

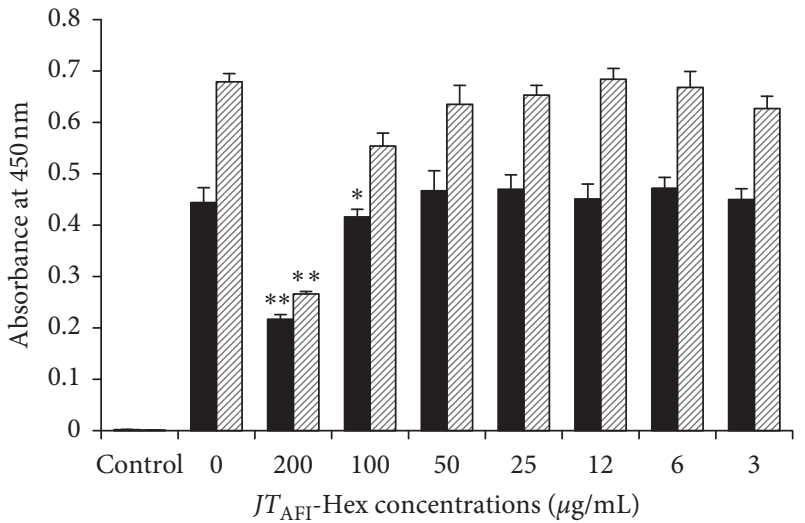

- $24 \mathrm{~h}$

曰 $48 \mathrm{~h}$

(b)

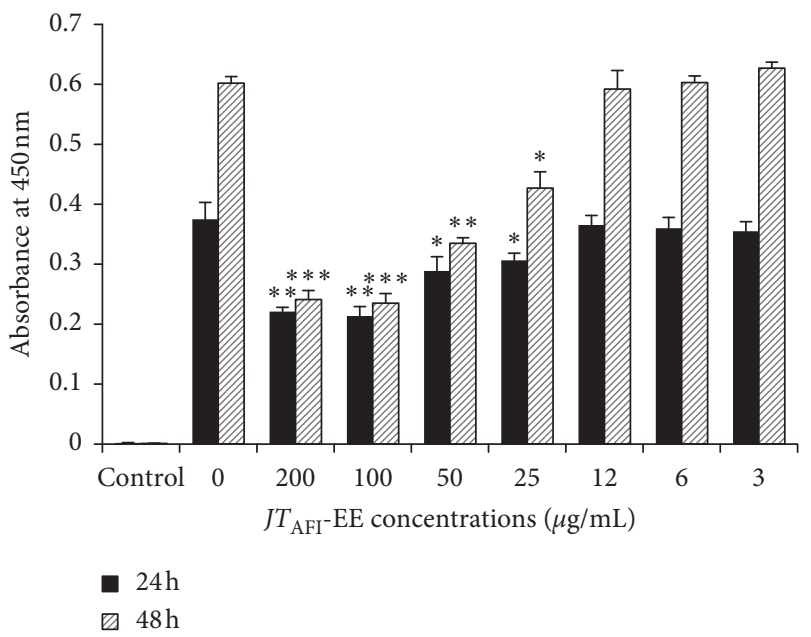

(d)

FIGURE 1: Effects of $J T_{\mathrm{YG}}$ and $J T_{\mathrm{AFI}}$ plant extracts on THP-1 cells viability. THP-1 macrophages were grown in the presence of indicated concentrations of $J T_{\mathrm{YG}}-\mathrm{Hex}(\mathrm{a}), J T_{\mathrm{AFI}}-\mathrm{Hex}(\mathrm{b}), J T_{\mathrm{YG}}-\mathrm{EE}(\mathrm{c})$, and $J T_{\mathrm{AFI}}-\mathrm{EE}$ (d) extracts for 24 and $48 \mathrm{~h}$. Cell viability was measured using the CCK-8 solution. Data are a summary of three independent experiments performed in duplicate and expressed as mean \pm SD. ${ }^{*} p<0.05$, ${ }^{* *} p<0.01,{ }^{* * *} p<0.0001$ are significantly different from untreated cells.

$J T_{\mathrm{AFI}}-\mathrm{Hex}$ extracts, respectively (Figures 2(b) and 2(c)). However, only $J T_{\mathrm{YG}_{\mathrm{G}}}-\mathrm{EE}$ at $10 \mu \mathrm{g} / \mathrm{mL}$ was able to significantly $(p=0.001)$ inhibit IL-1 $\beta$ gene expression (Figure 2(c)). Exposure to $10 \mu \mathrm{M}$ dexamethasone used as positive control significantly decreased LPS-stimulated mRNA levels of all tested molecules (Figure 2). Exposure to vehicle control DMSO had no effect on cytokine expression in LPS- stimulated cells (data not shown).
3.7. Plant Extracts Suppresses Secretion of Inflammatory Cytokines and Chemokines in THP-1 Macrophages. As the next step, we measured cytokine levels secreted into the medium when THP-1 macrophages were exposed to LPS $(1 \mu \mathrm{g} / \mathrm{mL})$ in the presence or absence of JT- Hex $(50 \mu \mathrm{g} / \mathrm{mL})$ and $J T-$ EE $(10 \mu \mathrm{g} / \mathrm{mL})$ extracts. After $24 \mathrm{~h}$, the culture medium was collected, and cytokine concentrations were measured with Luminex kit. All cytokine secretion 


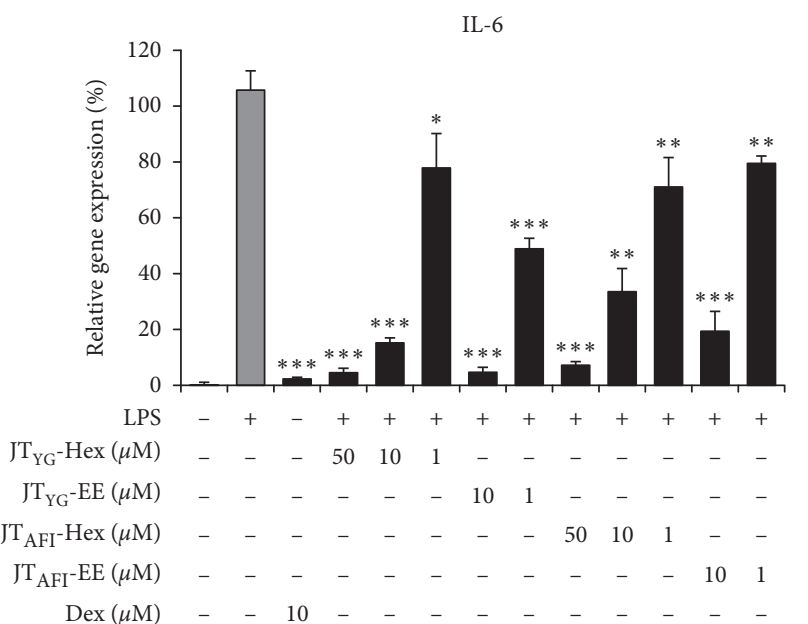

(a)
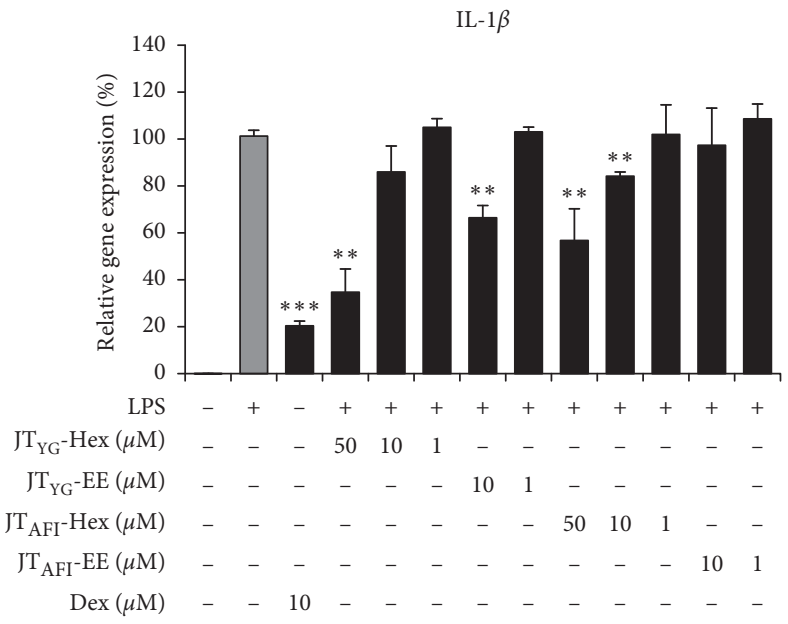

(c)

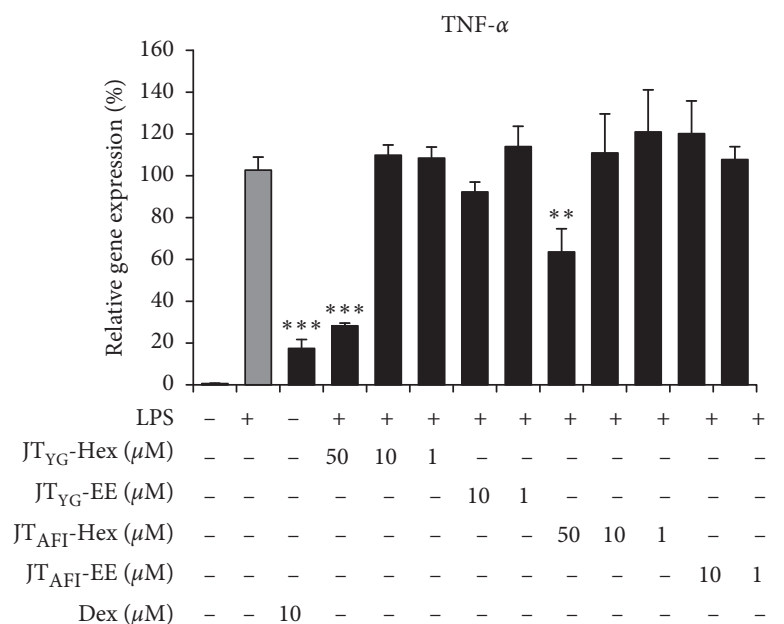

(b)

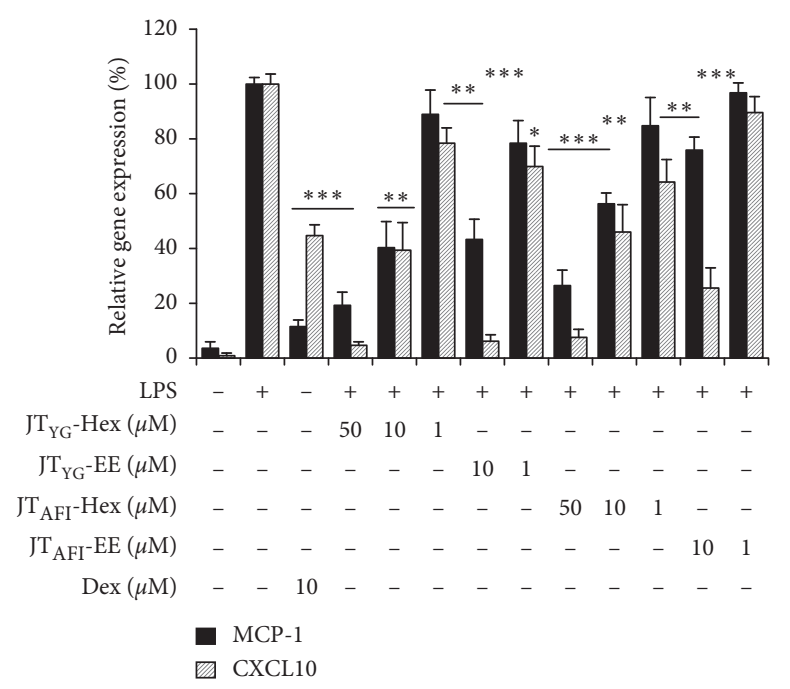

(d)

FIGURE 2: Suppression of proinflammatory cytokine and chemokine gene expression by JT extracts in THP-1 macrophages. Cells were treated $4 \mathrm{~h}$ with LPS $(1 \mu \mathrm{g} / \mathrm{mL})$ in the presence or absence of various concentrations of JT-EE and JT-Hex extracts. The levels of cytokine IL-6 (a), TNF- $\alpha$ (b), IL-1 $\beta$ (c), and chemokine MCP-1 and CXCL10 (d) mRNA were determined by real-time PCR. Data were normalized to $R$ pS29 and values were calculated using the comparative $\left(2^{-\Delta \mathrm{Ct}}\right)$ method. Results are mean \pm SD from at least three independent experiments. ${ }^{*} p<0.05,{ }^{* *} p<0.01,{ }^{* * *} p<0.0001$ are significantly different from LPS-stimulated cells.

significantly increased following macrophage treatment with LPS (Figure 3). $J T_{\mathrm{AFI}}-\mathrm{Hex}$ and $J T_{\mathrm{YG}}-\mathrm{Hex}$ extracts were able to significantly reduce the secretion of IL-6, IL-1 $\beta$, MCP-1, and CXCL10 from macrophages (Figure 3). IL-6, MCP-1, and CXCL10 secretion was also significantly decreased by both JT-EE extracts (Figures 3(a), 3(c), and 3(d)). However, only $J T_{\mathrm{YG}}$-EE extract at $10 \mu \mathrm{g} / \mathrm{mL}$ significantly decreased LPS-stimulated secretion of IL-1 $\beta(p=0.005$, Figure $3(b))$.

\section{Discussion}

The reverse pharmacology approach can be applied to study formulations used in Ayurveda to understand their mode of actions. Few reports have offered clear underlying mechanisms of synergistic therapeutic actions of herbal ingredients [32]. This study attempts to understand the potentials of both traditional $J T$ versions and the biological activities of hexane and ethanol extracts of herbal fractions of $J T_{\mathrm{AFI}}$ and $J T_{\mathrm{YG}}$ formulations in vitro.

So far, the wound healing mechanisms and efficacy of the JT formulation have been investigated using in vivo excision wound model and burn injury in rats $[15,33]$. The authors reported faster wound healing process in rats treated with JT due to increased proliferation of fibroblasts, protein synthesis, enhanced collagen formation, reepithelization, and wound contracting ability. However, to the best of our knowledge, there are no studies on antimicrobial and antiinflammatory potential of JT. Therefore, this study evaluated the antimicrobial and anti-inflammatory activities of ethanol and hexane extracts obtained from both $J T_{\mathrm{YG}}$ and $J T_{\mathrm{AFI}}$ formulations. $J T_{\mathrm{AFI}}$ formulation is composed of thirteen herbal ingredients along with copper sulfate fortified in oil. 


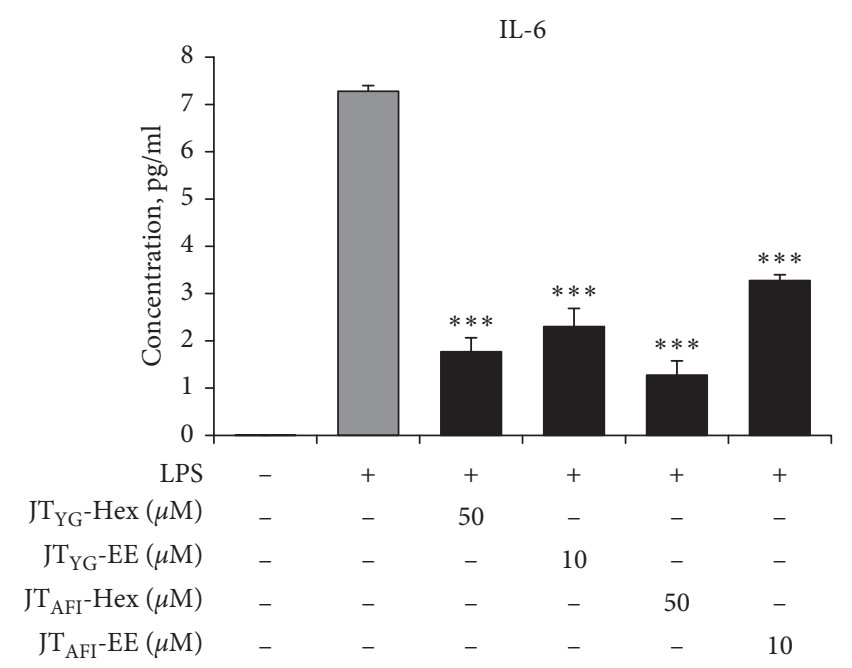

(a)

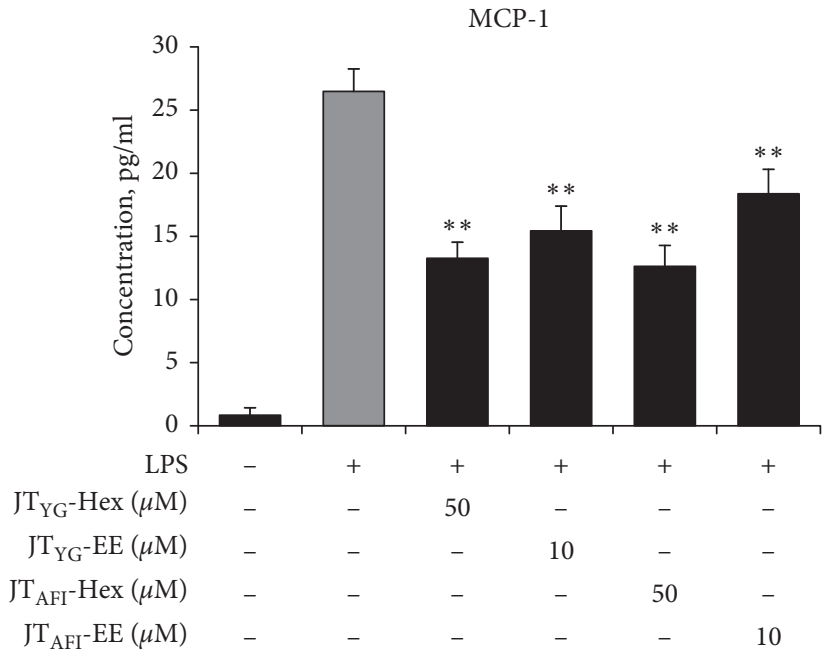

(c)

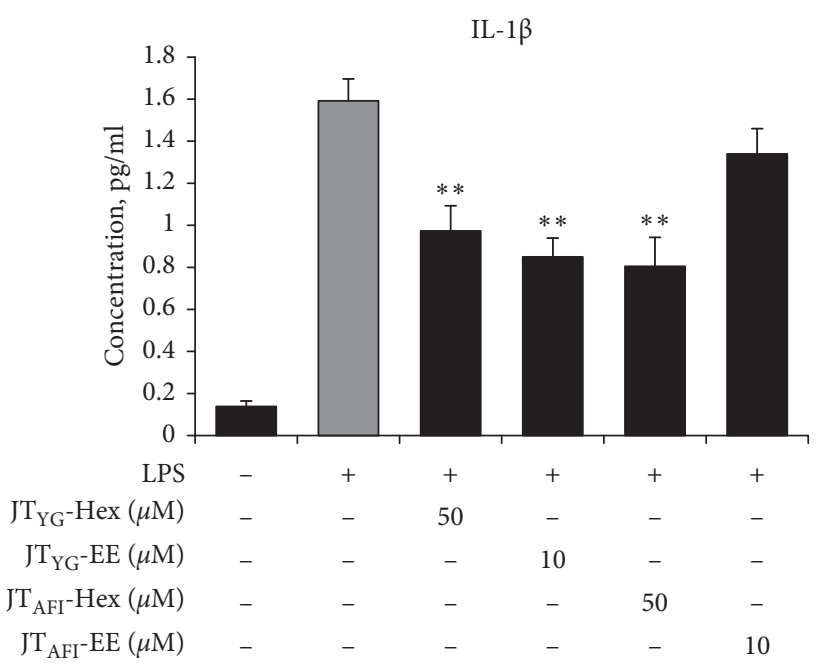

(b)

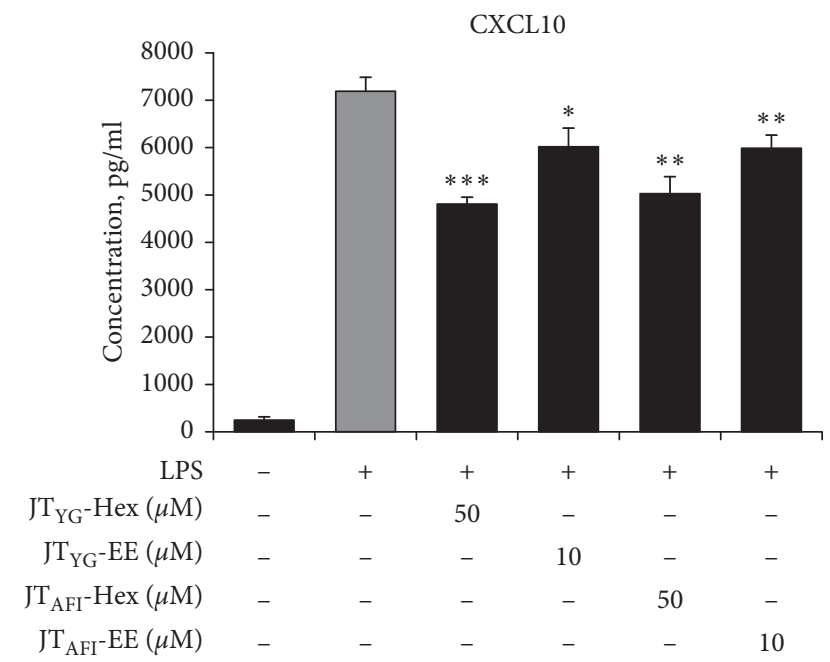

(d)

FIGURE 3: Suppression of proinflammatory cytokine and chemokine secretion by JT extracts in THP-1 macrophages. Supernatants from $4 \mathrm{~h}$ LPS and/or extracts-treated THP-1 macrophages were subjected to Luminex assay to detect proinflammatory cytokine IL-6 (a) and IL-1 $\beta$ (b) and chemokine MCP-1 (c) and CXCL10 (d) levels. Results are mean \pm SD from three independent experiments. ${ }^{*} p<0.05,{ }^{* *} p<0.01$, ${ }^{*} p<0.0001$ are significantly different from LPS-stimulated cells.

This study focuses only on the herbal fractions of both JT formulations. $J T_{\mathrm{AFI}}$ was evaluated without copper sulfate to understand the role of herbal combinatorics, as the efficacy of copper sulfate for its antimicrobial [34] and wound healing activity is well established [35].

Recent studies using molecular methods such as $16 \mathrm{~S}$ rRNA sequencing on diabetic ulcers revealed much higher levels of microbial diversity, especially more anaerobes and Gram (-) species than those previously known through culture-based methods [36]. Other bacteria involved in DFI in Europe, as revealed by conventional culturing, include P. mirabilis, $P$. aeruginosa, Klebsiella spp., E. coli, and anaerobes [37]. Contrary to this, in warmer countries (particularly in Asia and Africa), aerobic Gram (-) bacilli, especially $P$. aeruginosa, are more often the cause of DFIs. The antibacterial activity of $J T$ extracts was evaluated against both Gram (+) and Gram (-) reference bacterial strains and against four $S$. aureus strains isolated from clinically infected diabetic foot ulcers. We observed that all JT extracts showed better inhibitory activity for Gram (+) bacteria than Gram (-) strains. Notably, Gram (-) bacteria were susceptible only to EE extracts, except in the case of bacterial strain $P$. aeruginosa MDR ATCC BAA-2108. This can be explained by the higher presence of phenols, tannins, sterols, and flavonoids in EE extracts. A direct correlation between the summary content of phenols and flavonoids and antibacterial activity of different plant extracts has been reported [38].

Interestingly, the most potent antibacterial activity of JT extracts was observed against the reference bacterial strains, namely, S. aureus (MRSA, MSSA) and S. epidermidis. Moreover, the extracts were effective against all four clinical strains of $S$. aureus, with the highest MIC value of $7.81 \mathrm{mg} /$ $\mathrm{mL}$ for $J T_{\mathrm{YG}}-\mathrm{Hex}$ extract and varying in MICs from 1.95 to 
$62.5 \mathrm{mg} / \mathrm{mL}$ among clinical strains and $J T_{\mathrm{YG}}-\mathrm{EE}, J T_{\mathrm{AFI}^{-}}-\mathrm{EE}$, and $J T_{\mathrm{AFI}}-\mathrm{Hex}$ extracts. It has been shown that $S$. aureus is the most common pathogen among the Gram (+) bacteria isolated from infected diabetic foot wounds [39, 40]. Moreover, both S. aureus and S. epidermidis strains are able to form biofilms in a number of chronic wound states, including DFIs, which appear to impair wound healing by delaying wound reepithelization, reducing the effects of antimicrobials and immune response, and further increasing the infection of the wound [41].

In the recent past, treating DFIs has become more challenging due to the increased prevalence of multidrugresistant pathogens, particularly MRSA. Interestingly, the prevalence of MRSA in DFI varies among countries with an increase in less developed countries [8]. Therefore, we have elucidated the antibacterial activity of JT-EE and JT-Hex extracts against two predominant multiresistant bacteria found in diabetic wounds-MRSA and MDR P. aeruginosa. All four extracts had the greatest potential value against MRSA, with the highest inhibitory activity by ethanol extracts of both JT formulations with MIC $15.60 \mathrm{mg} / \mathrm{mL}$ and following hexane fractions with MIC $31.25 \mathrm{mg} / \mathrm{mL}$. However, only $J T_{\mathrm{YG}}-\mathrm{Hex}$ and $J T_{\mathrm{AFI}}-\mathrm{EE}$ extracts were able to inhibit the growth of the Gram (-) MDR P. aeruginosa, albeit with a higher MIC value of $62.5 \mathrm{mg} / \mathrm{mL}$. The antibacterial effect of JT extracts found in this study could be one of the mechanisms, which accelerates wound healing activity and thus supports its traditional use.

Such microbial infections and higher levels of biofilm in chronic wounds could influence the activity of the cells involved in wound healing and the composition of secreted cytokines and growth factors. Proinflammatory cytokines in the wound are required for initiating normal wound repair, but their increased expression levels are required only transiently. Moreover, both bacteria and their produced endotoxins can lead to the prolonged elevation of proinflammatory cytokines such as IL- $1 \beta$, IL-6, and TNF- $\alpha$ and downregulation of the anti-inflammatory cytokines TGF- $\beta$ and IL-10 in diabetic wounds, resulting in prolonged inflammation stage of wound healing [5]. The present study explored whether $J T$ extracts were able to modulate inflammatory activity in LPS-challenged THP-1 macrophage cells. Our results showed that all JT plant extracts dosedependently decreased IL-6, MCP-1 and CXCL10 gene expression and protein secretion in THP-1 macrophages in response to LPS; however, only $J T_{\mathrm{YG}}-\mathrm{EE}$ was able to significantly reduce the protein secretion and gene expression of IL- $1 \beta$ cytokine. Hexane extracts of both JT formulations also showed the potency to modulate TNF- $\alpha$ gene expression. The JT extracts could be able to normalize overexpressed cytokines in chronic wounds and, therefore, could shorten the prolonged inflammation.

In the present study, the phytochemical analysis and GCMS showed the presence of a considerable number of bioactive compounds and phytochemicals like flavonoids, terpenoids, sterols, glycosides, and fatty acids in the JT plant extracts, which can contribute to their antibacterial and antiinflammatory activities. It has been shown that saponins, flavonoids, and phenols possess potent anti-inflammatory and antifungal activity. Terpenoids exhibit antibacterial activity and play an active role in wound healing, increase the concentration of antioxidants in wounds and restore inflamed tissues [42]. Furthermore, the JT- Hex extracts were rich in ar-turmerone, $a$-turmerone, and $\beta$-turmerone, which are the major compounds in the essential oils of turmeric from Curcuma longa. Several studies have demonstrated that turmeric essential oils possessed potent antibacterial activity against a wide range of bacteria such as S.aureus, E.coli, P.aeruginosa, and B.subtilis [43-45]. Other phytoconstituents in $J T$ extracts, such as squalene from Cynodon dactylon, phytol from Erythrina variegate and Azadirachta indica, and stigmasterol derived from Pongamia pinata may also contribute to the biological effects of the JT extracts. Studies have demonstrated that squalene promotes remodelling and tissue repair response signals by inhibiting the nuclear factor-kappa $\mathrm{B}$, inducible nitric oxide synthase, the production of proinflammatory cytokines, such as IL- $1 \beta$ and TNF- $\alpha$, and stimulation of anti-inflammatory cytokines IL-10 and IL-4 [46, 47]. The biological activities of phytol and phytosterols can be attributed to antiinflammatory activities through reduction of leukocyte and neutrophil migration, IL- $1 \beta$, IL- 6 , and TNF- $\alpha$ levels and oxidative stress, as well as antibacterial effects [48-50].

$J T$ extracts showed a considerable number of free fatty acids such as palmitic, oleic, linoleic, stearic acids, and their esters. Free fatty acids have shown a vital effect in the prevention of antibacterial growth by targeting the structure and function of bacterial cell walls and membranes and inflammatory process via modulation of nitric oxide and cytokine production at the wound site $[51,52]$.

\section{Conclusions}

This study provides evidence that the ethanol and hexane extracts of both JT formulations possess potent antibacterial activity against Gram (+) and, to a lesser extent, Gram (-) bacteria and play an essential role in the anti-inflammatory response to LPS in macrophages. So, the study provides a rationale for the synergistic contribution of various herbs in the use of JT in the management of nonhealing wounds.

\section{Data Availability}

All data used during this study are available from the corresponding author.

\section{Conflicts of Interest}

The authors declare that they have no conflicts of interest.

\section{Acknowledgments}

The authors are grateful to Kaspars Jekabsons (University of Latvia, Faculty of Medicine, Department of Pharmacology) for his help with the statistical analysis. The research was funded by the Effective Collaboration Project from University of Latvia and AVP Research Foundation (Grant no. ZD2016/20226). 


\section{References}

[1] B. A. Lipsky, A. R. Berendt, P. B. Cornia et al., "2012 infectious diseases society of America clinical practice guideline for the diagnosis and treatment of diabetic foot infections," Clinical Infectious Diseases, vol. 54, no. 12, pp. e132-e173, 2012.

[2] N. H. Cho, J. E. Shaw, S. Karuranga et al., "IDF Diabetes Atlas: global estimates of diabetes prevalence for 2017 and projections for 2045," Diabetes Research and Clinical Practice, vol. 138, pp. 271-281, 2018.

[3] M. P. Rodero and K. Khosrotehrani, "Skin wound healing modulation by macrophages," International Journal of Clinical and Experimental Pathology, vol. 3, no. 7, pp. 643-653, 2010.

[4] R. E. Mirza, M. M. Fang, E. M. Weinheimer-Haus, W. J. Ennis, and T. J. Koh, "Sustained inflammasome activity in macrophages impairs wound healing in type 2 diabetic humans and mice," Diabetes, vol. 63, no. 3, pp. 1103-1114, 2014.

[5] G. Zhao, M. L. Usui, R. A. Underwood et al., "Time course study of delayed wound healing in a biofilm-challenged diabetic mouse model," Wound Repair and Regeneration, vol. 20, no. 3, pp. 342-352, 2012.

[6] S. E. Dowd, R. D. Wolcott, Y. Sun, T. McKeehan, E. Smith, and D. Rhoads, "Polymicrobial nature of chronic diabetic foot ulcer biofilm infections determined using bacterial tag encoded FLX amplicon pyrosequencing (bTEFAP)," PLOS One, vol. 3, no. 10, Article ID e3326, 2008.

[7] M. Malone, K. Johani, S. O. Jensen et al., "Next generation DNA sequencing of tissues from infected diabetic foot ulcers," EBioMedicine, vol. 21, pp. 142-149, 2017.

[8] C. Dunyach-Remy, C. Ngba Essebe, A. Sotto, and J.-P. Lavigne, "Staphylococcus aureus toxins and diabetic foot ulcers: role in pathogenesis and interest in diagnosis," Toxins, vol. 8, no. 7, p. 209, 2016.

[9] P. Rao, Bhaishajya Kalpana Vijnanam, pp. 250-274, Chaukhamba Publications, Varanasi, India, 2013.

[10] Ayurvedic Formulary of India (AFI), Part Ipp. 75-247, Government of India, Ministry of Health and Family Welfare, Department of Indian system of Medicines and Homeopathy, New Delhi, India, 2nd edition, 2003.

[11] B. Kumar, M. Vijayakumar, R. Govindarajan, and P. Pushpangadan, "Ethnopharmacological approaches to wound healing-exploring medicinal plants of India," Journal of Ethnopharmacology, vol. 114, no. 2, pp. 103-113, 2007.

[12] M. Kumar, "Jaatyadi Ghrita and its use in treating vrana (wound)," International Research Journal of Pharmacy, vol. 5, no. 3, pp. 128-130, 2014.

[13] Y. Kulkarni, S. Emmi, T. Dongargaon, and A. Wali, "Wound healing effect of Vimlāpanakarma with Jātyādi tailam in diabetic foot," Ancient Science of Life, vol. 34, no. 3, pp. 171-174, 2015.

[14] S. Singh and K. Rajoria, "Ayurvedic management of lifethreatening skin emergency erythroderma: a case study," $A Y U$ (An International Quarterly Journal of Research in Ayurveda), vol. 36, no. 1, pp. 69-72, 2015.

[15] S. Shailajan, S. Menon, S. Pednekar, and A. Singh, "Wound healing efficacy of Jatyadi Taila: in vivo evaluation in rat using excision wound model," Journal of Ethnopharmacology, vol. 138, no. 1, pp. 99-104, 2011.

[16] P. S. Jamadagni, S. Jamadagni, K. Mukherjee et al., "Experimental and histopathological observation scoring methods for evaluation of wound healing properties of Jatyadi Ghrita," Ayu, vol. 37, no. 3-4, pp. 222-229, 2016.
[17] S. R. Ayyar, P Vaidhyaratnam, and S. Warrier's, pp. 97-98, Arya Vaidhya Sala, Kottakal, India.

[18] B. Vijakumar, P. N. Rao, and K. P. Hemant, "A Case discussion on Dushta vrana (chronic wound)," International Journal of Ayurvedic Medicine, vol. 3, no. 1, pp. 53-57, 2012.

[19] Ayurvedic pharmacopoeia of India (API), Part Ipp. 33-34, Government of India, Ministry of Health and Family Welfare, Department of AYUSH, New Delhi, India, 1st edition, 2008.

[20] W. C. Evance, Trease and Evans' Pharmacognosypp. 96-98, Harcourt, Brace, San Diego, CA, USA, 14th. edition, 1997.

[21] S. Kamtekar, V. Keer, and V. Patil, "Estimation of phenolic content, flavonoid content, antioxidant and alpha amylase inhibitory activity of marketed polyherbal formulation," Journal of Applied Pharmaceutical Science, vol. 4, no. 9, pp. 061-065, 2014.

[22] H. P. S. Makkar, "Measurement of total phenolics and tannins using Folin-Ciocalteu method," in Quantification of Tannins in Tree and Shrub FoliageSpringer, Berlin, Germany, 2003.

[23] J. Zhishen, T. Mengcheng, and W. Jianming, "The determination of flavonoid contents in mulberry and their scavenging effects on superoxide radicals," Food Chemistry, vol. 64, no. 4, pp. 555-559, 1999.

[24] C. Egbuna, J. C. Ifemeje, M. C. Maduako et al., "Phytochemical test methods: qualitative, quantitative and proximate analysis," In Phytochemistry Fundamentals, Modern Techniques, and Applications, Apple Academic Press, New York, NY, USA, 2018.

[25] P. Brenac and Y. Sauvaire, "Accumulation of sterols and steroidal sapogenins in developing fenugreek pods: possible biosynthesis in situ," Phytochemistry, vol. 41, no. 2, pp. 415-422, 1996.

[26] J. B. Harborne, Phytochemical Methods: A Guide to Modern Techniques of Plant Analysis, Chapman \& Hall, London, 3rd edition, 1998.

[27] R. K. Upadhyay, M. B. Pandey, R. N. Jha, V. P. Singh, and V. B. Pandey, "Triterpene glycoside fromTerminalia arjuna," Journal of Asian Natural Products Research, vol. 3, no. 3, pp. 207-212, 2001.

[28] W. Yam, K. Ohtani, R. Hasai et al., "Steroidal saponins from fruits of Tribulus terrestris," Phytochemistry, vol. 42, no. 5, pp. 1417-1422, 1996.

[29] O. Lowry, N. Rosebrough, A. L. Farr, and R. Randall, "Protein measurement with the Folin phenol reagent," Journal of Biological Chemistry, vol. 193, no. 1, pp. 265-275, 1951.

[30] Clinical and Laboratory Standards Institute, Performance Standards for Antimicrobial Susceptibility Testing. CLSIM100-S27, CLSI M02-A12, p. 282, 27th edition, Clinical and Laboratory Standards Institute, Pennsylvania, PA, USA, 2017.

[31] M. Balouiri, M. Sadiki, and S. K. Ibnsouda, "Methods for in vitro evaluating antimicrobial activity: a review," Journal of Pharmaceutical Analysis, vol. 6, no. 2, pp. 71-79, 2016.

[32] Y. Yang, Z. Zhang, S. Li, X. Ye, X. Li, and K. He, "Synergy effects of herb extracts: pharmacokinetics and pharmacodynamic basis," Fitoterapia, vol. 92, no. 2, pp. 133-147, 2014.

[33] P. P. Dhande, S. Raj, N. I. Kureshee et al., "Burn wound healing potential of Jatyadi formulations in rats," Research Journal of Pharmaceutical, Biological and Chemical Sciences, vol. 3, no. 4, pp. 747-754, 2012.

[34] F. M. Aarestrup and H. Hasman, "Susceptibility of different bacterial species isolated from food animals to copper sulfate, zinc chloride and antimicrobial substances used for disinfection," Veterinary Microbiology, vol. 100, no. 1-2, pp. 83-89, 2004. 
[35] C. K. Sen, S. Khanna, M. Venojarvi et al., "Copper-induced vascular endothelial growth factor expression and wound healing," American Journal of Physiology-Heart and Circulatory Physiology, vol. 282, no. 5, p. H1821, 2002.

[36] K. Smith, A. Collier, E. M. Townsend et al., "One step closer to understanding the role of bacteria in diabetic foot ulcers: characterising the microbiome of ulcers," BMC Microbiology, vol. 16, no. 1, p. 54, 2016.

[37] W. Xavier, M. T. Sukumaran, A. K. Varma et al., "Emergence of multi drug resistant bacteria in diabetic patients with lower limb wounds," Indian Journal of Medical Research, vol. 140, no. 3, pp. 435-437, 2014.

[38] D. P. Basak, T. Adhikary, P. Das, and S. Biswas, "Phytochemical analysis and comparative study of antibacterial effect of turmeric extracts using different solvent," IOP Conference Series: Materials Science and Engineering, vol. 410, Article ID 012018, 2018.

[39] Y. Ge, D. MacDonald, H. Hait et al., "Microbiological profile of infected diabetic foot ulcers," Diabetic Medicine, vol. 19, no. 12, pp. 1032-1034, 2002.

[40] S. E. Gardner, S. L. Hillis, K. Heilmann, J. A. Segre, and E. A. Grice, "The neuropathic diabetic foot ulcer microbiome is associated with clinical factors," Diabetes, vol. 62, no. 3, pp. 923-930, 2013.

[41] C. F. Schierle, M. De la Garza, T. A. Mustoe, and R. D. Galiano, "Staphylococcal biofilms impair wound healing by delaying reepithelialization in a murine cutaneous wound model," Wound Repair and Regeneration, vol. 17, no. 3, pp. 354-359, 2009.

[42] J. R. S. Rex, N. M. S. A. Muthukumar, and P. M. Selvakumar, "Phytochemicals as a potential source for anti-microbial, antioxidant and wound healing - a review," MOJ Bioorganic \& Organic Chemistry, vol. 2, no. 2, pp. 61-70, 2018.

[43] P. S. Negi, G. K. Jayaprakasha, and K. K. Sakariah, “Antibacterial activity of turmeric oil: a byproduct from curcumin manufacture," Journal of Agricultural and Food Chemistry, vol. 47, no. 10, pp. 4297-4300, 1999.

[44] R. Singh, R. Chandra, M. Bose et al., "Antibacterial activity of Curcuma longa rhizome extract on pathogenic bacteria," Current Science, vol. 83, no. 6, pp. 737-740, 2002.

[45] L. Czernicka, A. Grzegorczyk, Z. Marzec, B. Antosiewicz, A. Malm, and W. Kukula-Koch, "Antimicrobial potential of single metabolites of Curcuma longa assessed in the total extract by thin-layer chromatography-based bioautography and image analysis," International Journal of Molecular Sciences, vol. 20, no. 4, p. 898, 2019.

[46] C. Li, F. Xi, J. Mi et al., "Two new 3,4;9,10-secocycloartane type triterpenoids from Illicium difengpi and their anti-inflammatory activities," Evidence Based Complementary and Alternative Medicine, vol. 2013, Article ID 942541, 9 pages, 2013.

[47] C. Sanchez-Quesada, A. Lopez-Biedma, E. Toledo et al., "Squalene Stimulates a Key innate immune cell to Foster wound healing and Tissue repair," Evidence Based Complementary and Alternative Medicine, vol. 2018, Article ID 9473094, 2018.

[48] A. Navarro, B. De las Heras, and A. Villar, "Anti-inflammatory and immunomodulating properties of a sterol fraction from Sideritis foetens," Biological and Pharmaceutical Bulletin, vol. 24, no. 5, pp. 470-473, 2011.

[49] R. O. Silva, F. B. M. Sousa, S. R. B. Damasceno et al., "Phytol, a diterpene alcohol, inhibits the inflammatory response by reducing cytokine production and oxidative stress,"
Fundamental \& Clinical Pharmacology, vol. 28, no. 4, pp. 455-464, 2014.

[50] M. T. Islam, S. A. Ayatollahi, S. M. N. K. Zihad et al., "Phytol anti-inflammatory activity: pre-clinical assessment and possible mechanism of action elucidation," Cellular and Molecular Biology, vol. 66, no. 4, pp. 264-269, 2020.

[51] B. Yoon, J. Jackman, E. Valle-González, and N.-J. Cho, "Antibacterial free fatty acids and monoglycerides: biological activities, experimental testing, and therapeutic applications," International Journal of Molecular Sciences, vol. 19, no. 4, p. 1114, 2018.

[52] C. Ribeiro Barros Cardoso, M. Aparecida Souza, E. Favoreto, and J. Deolina Oliveira Pena, "Influence of topical administration of n-3 and n-6 essential and n-9 nonessential fatty acids on the healing of cutaneous wounds," Wound Repair and Regeneration, vol. 12, no. 2, pp. 235-243, 2004. 